\title{
Monitoring and Modelling of Butyltin Compounds in Finnish Inland Lake
}

Heidi Ahkola ( $\nabla$ heidi.ahkola@syke.fi )

Finnish Environment Institute (SYKE) https://orcid.org/0000-0002-3329-3749

Janne Juntunen

Finnish Environment Institute: Suomen ymparistokeskus

Kirsti Krogerus

Finnish Environment Institute: Suomen ymparistokeskus

Timo Huttula

Finnish Environment Institute: Suomen ymparistokeskus

\section{Research Article}

Keywords: butyltin compounds, monitoring, surface water, modelling, back tracking simulation, passive sampling

Posted Date: November 1st, 2021

DOl: https://doi.org/10.21203/rs.3.rs-968917/v1

License: (1) (1) This work is licensed under a Creative Commons Attribution 4.0 International License. Read Full License 
2 inland lake

3 Heidi Ahkola*, Janne Juntunen, Kirsti Krogerus, Timo Huttula

4 Finnish Environment Institute (SYKE), Survontie 9 A, 40500 Jyväskylä, Finland

$5 *$ corresponding author

6 Contact information of corresponding author:

7 Heidi Ahkola

8 Finnish Environment Institute (SYKE)

9 Survontie 9 A

1040500 Jyväskylä, Finland

11 Email: heidi.ahkola@syke.fi

12 Tel: +358 400966821

13 Fax: -

\section{Abstract}

Butyltin compounds (BTCs) in surface waters is seldom studied due to their low concentrations and limitations of analytical techniques. In this study we measured total concentration of BTCs with grab water sampling, dissolved concentration with passive samplers and particle bound fraction with sedimentation traps in Finnish inland lake. The sampling was conducted from May to September during two study years. The differences between sampling techniques and the concentrations were obvious. E.g. tributyltin (TBT) was detected only in 4-24\% of the grab samples when the detection with passive samplers was $93 \%$ and with sedimentation traps 50\%. The dissolved BTC concentrations measured with grab and passive sampling suggested hydrological differences between the study years. This was confirmed with flow velocity measurements. However, the annual difference was not observed in BTC concentrations of settled particle.

The extreme value analysis suggested that grab sampling and sedimentation trap sampling results contain more extreme peak values than passive sampling. This indicates that BTCs are present in surface water in trace concentrations despite they are not detected with all the sampling techniques.

The assumption that WWTP, located in the study area, was the source of BTCs was not valid as elevated BTC concentrations were detected also at the reference site, located upstream of WWTP. Computational modelling and back tracking simulations also supported the concept that WWTP cannot be the only source but BTCs can come even from upstream of the sampling area where there is e.g. wood processing industry. 


\section{Introduction}

Organotin compounds (OTCs) have been widely used in different industrial applications for over 50 years. (Champ and Seligman, 1996, Fent 1996, Hoch 2001, Dubalska et al. 2013) Due to their versatile properties OTCs have been utilized as biocides, pesticides, wood preservatives, catalysts and stabilizing agents in polymers due to their versatile properties. OTCs, especially tri-substituted ones, are toxic to variety of aquatic organisms (Bryan and Gibbs 1991, Hoch 2001, Aguilar-Martinez et al. 2008a) and the hazardousness of tributyltin (TBT) for aquatic organisms appears below $n g \mathrm{~L}^{-1}$ concentration levels (Bryan and Gibbs 1991, Díez et al. 2002). The Annual Average Environmental Quality Standard (AA-EQS) concentration for TBT is $0.2 \mathrm{ng} \mathrm{L}^{-1}$ and the maximum allowable concentration (MAC-EQS) $1.5 \mathrm{ng} \mathrm{L}^{-1}$ (EC 2008a). Considering low aquatic concentrations, the detection of OTCs requires sensitive analytical techniques.

The main source where tri-substituted OTCs entered to aquatic environment was their use in antifouling paints of ship industry (Champ and Seligman, 1996). In 1st July 2003 EU restricted the use of OTC containing ship paints in vessels flying the flag of EU country. (EC 2003). In 1st January 2008 the ships entering to EU country must either have paint with no OTCs or cover OTC-paint with OTC-free paint layer (EC 2008b). In 2010 the use of tri-substituted OTCs in items which include more than $0.1 \%$ by weight of tin was banned and in 2012 the restriction was extended to cover dibutyltin (DBT) and dioctyltin (DOT) EC 2009). Monobutyltin (MBT) and DBT have been used as PVC stabilizers in packaging materials from which they can leach to foodstuff and beverages (Takahashi et al. 1999, Hoch 2001). Despite the restrictions these substances are still found in Finnish inland waters where they are released for example via wastewater treatment plants (WWTP) (Mannio 2011, Vieno 2014, Ahkola et al. 2015).

Estimation of the sources and transport of BTC's and especially TBT is difficult due to their low aquatic concentrations. BTCs are highly attracted by solid particles or bioaccumulated and commonly determined in sediment samples or aquatic organisms (Page et al. 1996, Harino et al. 1998, Berto et al. 2007, Cole et al 2018). They also have long transformation chain from tertbutyltin (TeBT) to MBT 
59 (ultraviolet UV irradiation), bacteria (biological cleavage) or nucleophile or electrophile reagents (chemical 60 cleavage) (Hoch 2001). The transformation rates are slow when BTCs are attached to particles but notably

61 faster as they are in their dissolved form (Juntunen et al. 2020). In water column TBT loss occurs mainly

62 via microbial transformation or adsorption to particles (Stewart and de Mora 1990). When TBT concentration is low, e.g. in surface water, the bacteria transform it readily, whereas high concentrations of TBT enriched to sediments inhibits the bacterial activity. The degradation of BTCs in natural waters is poorly reported which can be due to low aquatic concentrations and limits of analysing techniques. The studies consider mainly the degradation of TBT in marine environment with tests conducted in a laboratory conditions (Lee et al. 1989; Seligman et al. 1988) or using microbes isolated from sea water (Harino et al. 1997; Kawai et al 1998, Sampath et al. 2012). However, these results cannot be directly applied to Finnish inland waters due to differences of microbes and high content of humic substances. The half-life of biological transformation of TBT varies from three days to several weeks depending on the water matrix and prevailing test conditions ( $\mathrm{pH}$, temperature, turbidity, light) (Stewart and de Mora 1990; Dowson et al. 1996). Due to their low solubility the BTCs tend to attach to particles and sediment where their degradation is slow being from several weeks to years. The process is considerably slower in anaerobic than in aerobic sediments (Seligman et al. 1986). Sediments are still not a permanent sink for OTCs since due to mechanical resuspension they can dissolve back to water column (Page et al. 1996; Filipkowska et al. 2014). Particles can drift to unpolluted sites where e.g. tidal fluxes and dredging can cause resuspension of BTCs, favouring the DBT release over TBT (Dowson et al. 1993; Berto et al. 2007). In shallow lakes even waves created by storms and big boats can cause resuspension. Therefore, the dispersion of BTCs can be considered as potentially complex process.

Due to rather complex physical and chemical characteristics the behaviour of BTCs in aquatic environment requires complementary monitoring approaches. As the aquatic concentrations of BTCs are expected to be low, they can remain undetectable with conventional grab water sampling. Passive sampling techniques collect studied substances during the deployment time from days to weeks which enables the enrichment of trace concentrations to the measurable level. It has been recognised as a useful screening technique for several harmful substances (Kingston et al. 2000; Persson et al. 2001, Blom et al. 2002, Górecki and 
Namieśnik 2002; Vrana et al. 2005a, 2005b; 2009; Allan et al. 2007, de la Cal et al. 2008, Gunold et al. 2008, Sánchez-Bayo et al. 2013, Vermeirssen et al. 2013, Ahkola et al. 2013, 2014, 2015) and has been applied also in OTC monitoring (Aguilar-Martinez et al. 2008a, 2008b, 2011, Garnier et al. 2020). As a difference to grab sampling, that determines the total concentration of chemical, passive sampling collects only the dissolved part of the chemical which is considered to be the most bioavailable and most harmful part of the substance when considering the environmental effects (Kot et al. 2000, Aguilar-Martinez et al. 2008b). Passive samplers give time weighted average (TWA) concentration of chemical during the sampling period. TWA concentration is calculated based on the accumulated amount of chemical, deployment time and the sampling rate which has been determined in a calibration trial (Kingston et al. 2000; Vrana et al. 2006). Chemcatcher samplers has been developed and calibrated for detecting OTCs marine, sewage and inland waters (Aguilar-Martinez et al. 2008a, 2008b, 2011, Garnier et. al. 2020). As the passive samplers collect also undetermined, potentially bioavailable chemicals the sampler extracts have also been used in estimating toxicity of the freely dissolved chemical fraction (Jahnke et al. 2016).

Sedimentation traps were used to study the particle bound BTC fraction. The traps are deployed near the lake bottom for certain time priod (Bloesch and Burns, 1980, Schubert, et al. 2012, Kaitaranta et al. 2013, Wren at al 2019). Due to gravity the particles drifted with water flow will fall to the trap and the concentration of studied chemicals can be analysed from the particles.

The occurrence of BTCs (MBT, DBT and TBT) was studied in lake conditions with grab water-, passive , and sedimentation trap sampling to estimate the concentration of total, dissolved and particle bound BTC fraction. The results were used in modelling calculations to assess the source and transportation of BTCs in the study area. The results of different sampling techniques are evaluated with extreme value analysis to recognize high instant peak concentrations from the prevailing concentration levels.

\section{Experimental}

The BTCs were monitored with passive samplers, sedimentation traps, and grab water samples in boreal lake. Sampling campaigns were conducted at six sampling sites from May to September for two years (Fig. 
111 1). Passive samplers and sedimentation traps were deployed for two weeks' time period and grab samples

112 were taken as the samplers and traps were replaced with new ones. In the first study year ( $1^{\text {st }}$ year, 2012) 113 ten consecutive passive sampler and sedimentation trap deployments were conducted and in the second 114 year $\left(2^{\text {nd }}\right.$ year, 2013) the number of sampling occasions was eight. The number of grab sampling occasions 115 in 1 st and 2nd study year was 11 and 9, respectively. In addition to comprehensive monitoring campaign 116 we estimated computationally the probability that particles are released from the discharge pipe of the 117 wastewater treatment plant (WWTP), located at site 1.

\section{$118 \quad 2.1$ Study area}

119 The study area was located in northern Lake Päijänne (62 8.9467', 25 37.6913') in Central Finland (Fig. 1). The sampling site 1 is at the outflow of the WWTP which receives sewage waters from 150000 inhabitants as well as industrial waste waters (Lindholm-Lehto et al. 2018, Ahkola et al. 2016). During the study period the annual wastewater discharge was $40000 \mathrm{~m}^{3} \mathrm{~d}^{-1}$ and in the beginning of the field trials WWTP was assumed to be the main source of BTCs. Sites 3-5 are situated downstream from the WWTP. Sites 4 and 5 are situated at the deepest locations of the study area. Due to water currents wastewaters are able to drift to site 2 but site 6 was considered as reference site which receives no effluent waters from WWTP. Validity of this assumption was assessed by modelling the probability of transportation of particles originating from the WWTP (Chapter 3.7). Detailed information about the WWTP is described in Lindholm-Lehto et al. 2018. Upstream of the study area is continuous waterway having summer houses, boats and piers on the shore. Also, wood processing industry is located about $60 \mathrm{~km}$ north from the Lake Päijänne. In the beginning of this study the assumption was that the possible pollution sources upstream were negligible or so far that the transportation of BTCs via small waterway was unlikely. 


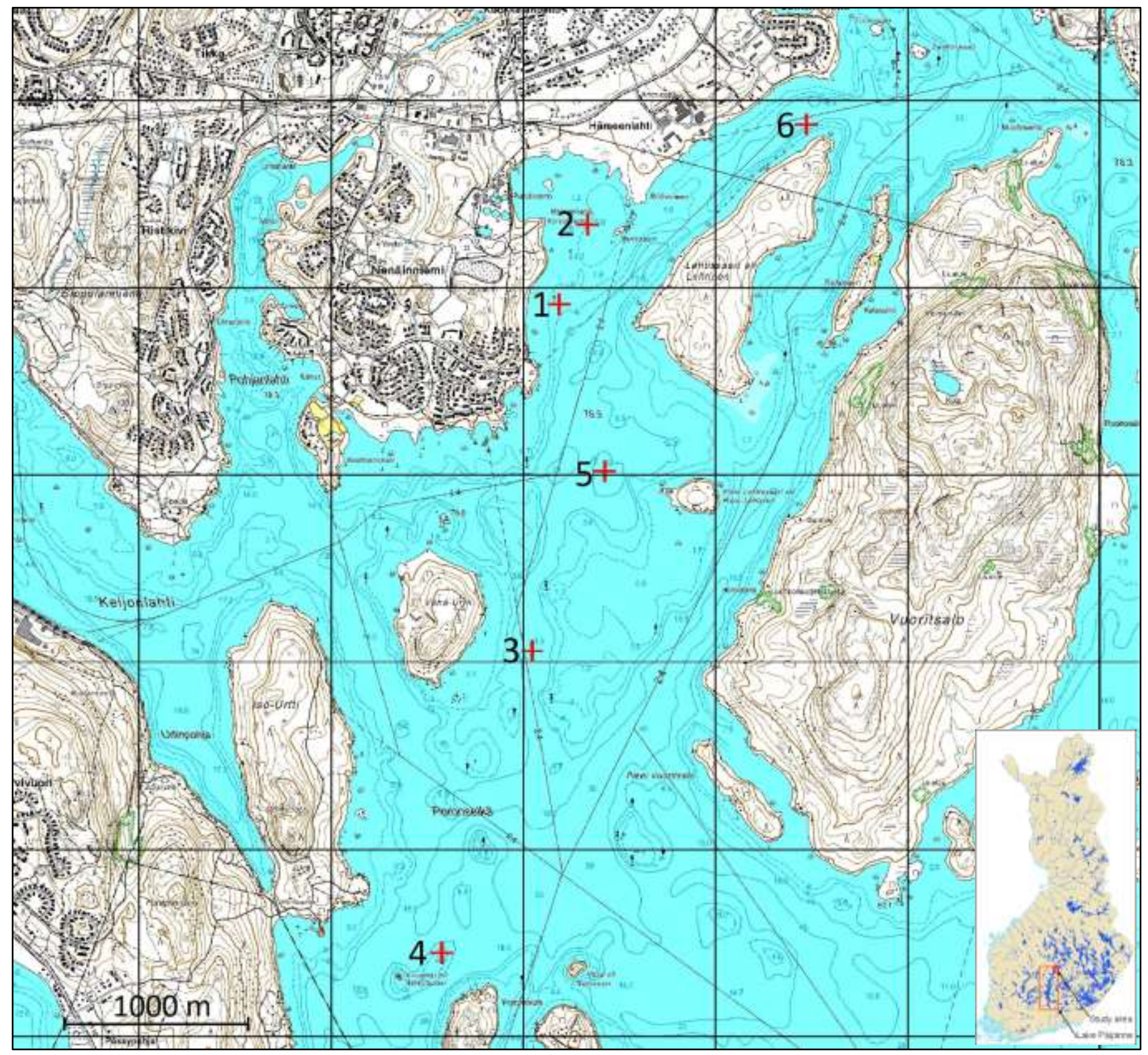

Fig. 1. Study area. The depth of the sites was $5 \mathrm{~m}$ (sites 1 and 2), $12 \mathrm{~m}$ (site 3), $20 \mathrm{~m}$ (site 4), $24 \mathrm{~m}$ (site 5) and $14 \mathrm{~m}$ (site 6). Rapid Vaajakoski, the main source for through flow, is located north-east outside the figure.

\subsection{Sediment sampling}

BTCs were determined in sediment samples cored with Limnos sediment sampler which contained series of rings and enabled the slicing of sediment layers at exact thickness of $1 \mathrm{~cm}$ (Kansanen et al. 1991). The samples were collected from five sampling sites (Fig. 1 sites $1,2,3,5,6)$ and three depths $(0-1 \mathrm{~cm}, 1-3 \mathrm{~cm}$ and 3-5 cm) to assess the presence of BTCs in old sediment layers. In the study area the sediment at depth of $5 \mathrm{~cm}$ is about 10 years old (Paasivirta et al. 1990). If the settling velocity and the water quality have remained quite the same the samples taken at depth $2-3 \mathrm{~cm}$ can be estimated to be about 5 years old. 
143

144

145

\subsection{Passive sampling}

Three replicate Chemcatcher passive samplers with C-18 Empore disk and polycarbonate housing (Ahkola et al. 2015, 2016) were deployed at each sampling site (1-6, Fig. 1) for two weeks after which they were retrieved and replaced with new ones. Samplers were deployed $1 \mathrm{~m}$ below water surface. The samplers accumulate dissolved fraction of the chemical which, after the deployment time period, is extracted from the sampler. TWA concentrations of dissolved BTCs during the two weeks sampling period were calculated with using sampling rates determined in Ahkola et al. (2015, 2016). Method detection limit (MDL) was calculated from the analytical limit of detection (ng sampler ${ }^{-1}$ ) after 14 days deployment (Table 1).

\subsection{Sedimentation traps}

Sedimentation traps were deployed at each sampling site (1-6, Fig. 1) to study the amount of settling particles and measure the particle bound fraction of BTCs. Duplicate traps were placed $1 \mathrm{~m}$ above the lake bottom where they collected settled particles for two weeks. After that the samples were collected to glass jars, and the traps redeployed. The excess water was decanted and discarded, and the samples were stored at $+4^{\circ} \mathrm{C}$ until analysis. BTCs were analysed from settled particles. The trap consisted of two acrylic tubes whose diameter (D) was $9.3 \mathrm{~cm}$ and the height $(\mathrm{H}) 50 \mathrm{~cm} \mathrm{H} / \mathrm{D}$ ratio being 5.4. The top part of the tube was open, but the bottom was sealed to trap the particles. The ratio of height and diameter (H/D) of the tube is essential to avoid the escaping of particles, Bloesch and Burns (1980) recommended H/D ratio of 5. According to Lau et al. (1979) the critical stream velocity at $15^{\circ} \mathrm{C}$ for $\mathrm{H} / \mathrm{D}$ ratio of 6.7 was $26.2 \mathrm{~cm} \mathrm{~s}^{-1}$ and for H/D 10 it was $27 \mathrm{~cm} \mathrm{~s}^{-1}$. In this study the ratio was 5.4 so the escaping velocity was $26.2 \mathrm{~cm} \mathrm{~s}^{-1}$. Such current velocities are extremely rare in Finnish lakes. In this study the currents were also measured at study sited (Chapter 2.7). The results are presented as dry weight (dw).

\subsection{Grab water sampling}

The concentrations of BTCs were monitored also with grab water samples which were taken every two weeks at the same time as the passive samplers and sedimentation traps were retrieved or emptied. The grab samples were taken in darkened glass bottles $(1 \mathrm{~L})$ from the depths of 1 meter below surface and one meter above the lake bottom. At sites 3-6 one grab sample was taken in the middle of the water column. Grab 
169

sampling was not conducted at site 3 in the $2^{\text {nd }}$ year. The samples were stored at $+4^{\circ} \mathrm{C}$ and they were not filtered before analysis. The results are presented as an average of concentrations which exceeded the limit of detection (LOD) (Table 1).

\subsection{Sample treatment and analysis}

The Chemcatcher passive sampler contained C-18 Empore disk receiving phase (47 mm diameter, $3 \mathrm{M}$ Agilent Technologies Finland Oy) attached to polycarbonate sampler housing (AlControl AB, Linköping, Sweden) (Ahkola et al. 2015). After deployment the internal standard (tri- $n$-propyltin) was added to the disk which was further extracted with acetic acid-methanol (3:1) in an ultrasonic bath for 10 minutes. The sample was let stand for 10 minutes and the ultra-sonication was repeated. $4 \mathrm{~mL}$ acetate buffer $(1 \mathrm{M}, \mathrm{pH}$ 5.4) was added, BTCs were derivatized with sodium tetraethylborate $\left(\mathrm{NaB}\left(\mathrm{C}_{2} \mathrm{H}_{5}\right)_{4}\right)$ and extracted from acetic acid-methanol-acetic acid mixture to hexane which was transferred to a sample vial and analysed with GC-ICP- MS (Agilent 6890N gas chromatograph coupled to Agilent 7500ce ICP-MS) (ISO 17353, 2004, Alonso et al. 2002). After the gas chromatographic separation of BTCs they were quantified according to Sn isotopes concentrations using internal standard technique and the results were expressed as concentration of each BTC species. The sediment samples and settled particles from sedimentation traps were treated according to passive sampler procedure and the BTC concentrations are expressed as dw. The internal standard (tri-n-propyltin), acetate buffer (1 M, pH 5.4) and sodium tetraethylborate $\left(\mathrm{NaB}\left(\mathrm{C}_{2} \mathrm{H}_{5}\right)_{4}\right)$ was added to the grab water samples, the BTCs were extracted to hexane and analysed with GC-ICP-MS Before analysis all the samples were stored at $+4^{\circ} \mathrm{C}$. The passive samplers, sediments and settled particles were analysed within 7 days of retrieving. The grab samples were analysed the day after sampling. Blank samples were processed and measured alongside every sample treatment. LOD for each sampling technique is presented in Table 1.

Table 1. LOD of each sampling technique.

\begin{tabular}{l|c|c|c}
\hline Sampling technique & MBT & DBT & TBT \\
\hline Grab sampling $\left(\mathrm{ng} \mathrm{L}^{-1}\right)$ & 0.50 & 0.50 & 0.20 \\
\hline Passive sampling $\left(\mathrm{ng} \mathrm{sampler}^{-1}\right)$ & 0.10 & 0.10 & 0.10 \\
\hline Passive sampling $\left(\mathrm{ng} \mathrm{L}^{-1}\right)$ & $0.016^{*}$ & $0.010^{*}$ & $0.0082^{*}$ \\
\hline Sedimented particles sampling $\left(\mu \mathrm{g} \mathrm{kg}^{-1} \mathrm{dw}\right)$ & 0.50 & 0.50 & 0.20 \\
\hline
\end{tabular}


193

194

195

196

197

198

199

200

201

202

203

204

205

206

207

208

209

210

211

212

213

\subsection{Monitoring of water flow}

The water flow was monitored with moored recording current meters (Aanderaa RCM-9) placed on sites 1, 2 and 3 to observe the water currents and to estimate the transportation of BTCs in the study area. The flow was measured at depths $1.1 \mathrm{~m}$ (site 1), $1.0 \mathrm{~m}$ (site 2) and $2.0 \mathrm{~m}$ (site 3) and currents were recorded as a ten-minute average. Current were measured for 3.5 months in both study years covering the time of monitoring campaigns.

\subsection{Computational estimation of BTC sources}

Computational simulation was conducted at the study area to estimate the transportation and distribution of BTCs in lake conditions. In computational transport modelling there are two fundamentally different approaches to consider dispersion of substances: Eulerian and Lagrangian. While in Eulerian approach concentration field is evaluated continuously for whole modelled area, in Lagrangian method trajectory for each particle is modelled individually. This kind of modelling approach enables back tracking calculation in time and enables estimation of the source of particles observed at the study area (Karjalainen et al. 2019).

To computationally estimate sources of BTCs and to create flow model for study area we used Coherens model V2.11.2 (Luyten 2013). Coherens is an ocean circulation model that solves Navier-Stokes equations using the Boussinesq approximation and the assumption of vertical hydrostatic equilibrium. The prime equations are solved in a horizontally uniform rectangular grid with the resolution of $100 \mathrm{~m}$ for both horizontal directions (84 and 115 grid cells in west-east and south-north directions, respectively) and with $10 \sigma$-layers. The model runs were started from the rest, i.e. initial values of 0 were used for currents and the temperature was adjusted to $5^{\circ} \mathrm{C}$. Simulation periods were 1.5.2012-20.9.2012 and 1.5.2013-5.9.2013 covering the whole sampling period.

Lagrangian particle module implemented to Coherens use currents to model the transportation of the individual particles. To consider the degradation path from TeBT to MBT we modified the particle module of Coherens to take account this transformation chain and used degradation rates presented in Juntunen et al. (2020). Different BTCs are represented as particles with differing properties. Same particle module 
218 without degradation chain has been used when estimating the reproducing strategies of larvae in surface 219 waters (Karjalainen et al. 2019).

220 The modelled area was the north part of the Lake Päijänne. Southern border was located in the middle of 221 the lake and considered to be far enough so the lack of actual flow data can be neglected. In the model we considered rapid Vaajakoski at north-east as an incoming boundary and that the discharge in the study area remained the same.

Two different situations were simulated with the model and the possible sources of BTCs was estimated. Constant presence of BTCs in the vicinity of the sampling sites was assumed. In the first simulation, one BTC particle for each species was released every minute during the two weeks passive sampler/sedimentation trap deployment time (20160 particles/2 weeks). In the second simulation, 20160 particles were released at once from the same locations as in the first case which now mimics the timing of instant grab water sampling. For both release types, either 20160 particles in two weeks or 20160 particles at once, the location of particles was back tracked to the beginning of simulation period. With back tracking calculation the probability that particles were released from the WWTP (site 1) was assessed.

\section{Results and discussion}

233 To explain the transportation phenomena, it is important to understand the water currents prevailing in the study area. Knowledge concerning the currents also promotes to estimate the probability of resuspension from sediments and hence the release of BTCs back to dissolved form. High flow velocity correlates rather well with the flow environment where instantaneous forces affect the suspended particulate matter and hence might release attached BTC from the particles. Furthermore, measured velocities can be used to estimate the accuracy of the computational model applied in this paper.

\subsection{Hydrological conditions and measured water currents}

240 The study years were hydrologically very different. The average inflow to Lake Päijänne during the study 241 period May-September was higher in the first year $\left(264 \mathrm{~m}^{3} \mathrm{~s}^{-1}\right)$ than the second one $\left(164 \mathrm{~m}^{3} \mathrm{~s}^{-1}\right)$ (Database for hydrological observations, SYKE). Also, the water levels during May-September differed being $230 \mathrm{~cm}$ 
243 in first study year and $212 \mathrm{~cm}$ in the second one. The runoff waters originated from watershed could have

244 brought more pollutants to study area.

245 When considering the flow velocity and current direction in lake (Table 1) the transportation of released 246 effluent from site 1 downstream to site 3 lasts about 0.5 days. Site 4 is located twice as far away so the 247 effluent reaches it in one day. Though the current is not moving straightforward to south but circulates, the results suggest that effluent can spread to the whole study area approximately in two days. The average water velocities during the two weeks sampling period varied especially at site 3 where the highest velocities occurred during the time period of the deployments 5 and $6\left(1^{\text {st }}\right.$ year $)$ and deployments 1 and 2 251 ( $2^{\text {nd }}$ year), being $5.8 \mathrm{~cm} \mathrm{~s}^{-1}$ and $5.0 \mathrm{~cm} \mathrm{~s}^{-1}$, respectively (Table 2). However, the velocities were clearly below the limit value $26.2 \mathrm{~cm} \mathrm{~s}^{-1}$ so the solid particles unlikely escaped from the trap. According to the measurements in Table 2 the water currents may circulate the effluent waters upstream from site 1 to the upstream site 2 occasionally. This observation is supported also by the modelling results. The flow roses (Fig. 2) show that currents from site 1 towards site 2 are higher during the $2^{\text {nd }}$ study year than in $1^{\text {st }}$ year.

The hydrological differences between the study years can be observed at site 3 where varying flow direction mix the water column during the $2^{\text {nd }}$ study year.

Table 2. Mean water velocity and average direction at sampling sites 1,2 and 3 during the study years.

\begin{tabular}{|c|c|c|c|c|c|c|}
\hline \multicolumn{2}{|c|}{ Sampling occasion } & $\begin{array}{c}\text { Site } 1 \\
\left(\mathrm{~cm} \mathrm{~s}^{-1}\right)\end{array}$ & \multicolumn{2}{|c|}{$\begin{array}{c}\text { Site } 2 \\
\left(\mathrm{~cm} \mathrm{~s}^{-1}\right)\end{array}$} & \multicolumn{2}{|c|}{$\begin{array}{c}\text { Site } 3 \\
\left(\mathrm{~cm} \mathrm{~s}^{-1}\right)\end{array}$} \\
\hline \multirow{8}{*}{$\begin{array}{l}\frac{1}{\pi} \\
\stackrel{D}{2} \\
\stackrel{5}{n}\end{array}$} & Deplyment 1 & 2.9 & 2.2 & 4 & 2.7 & \\
\hline & Deplyment 2 & 3.2 & 2.3 & & 3.3 & \\
\hline & Deplyment 3 & 3.2 & 2.6 & 4 & 2.0 & \\
\hline & Deplyment 4 & 2.9 & 3.3 & & 3.4 & \\
\hline & Deplyment 5 & 3.2 & 2.7 & & 4.9 & \\
\hline & Deplyment 6 & 3.5 & 3.1 & & 5.6 & \\
\hline & Deplyment 7 & 3.8 & 2.2 & & 2.5 & \\
\hline & Deplyment 8 & 3.9 & 2.3 & & 2.6 & \\
\hline \multirow{5}{*}{ 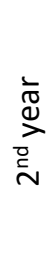 } & Deplyment 1 & & 2.5 & & 5.8 & \\
\hline & Deplyment 2 & & 2.1 & & 5.0 & \\
\hline & Deplyment 3 & 2.0 & 2.7 & & 3.2 & \\
\hline & Deplyment 4 & 5.0 & 2.9 & 4 & 3.1 & \\
\hline & Deplyment 5 & 3.9 & 2.7 & & 2.7 & \\
\hline
\end{tabular}


Fig. 2. Flow rose figures for sites 1,2 and 3 (from top to bottom) for both study years, $1^{\text {st }}$ year on the left and second year on the right.
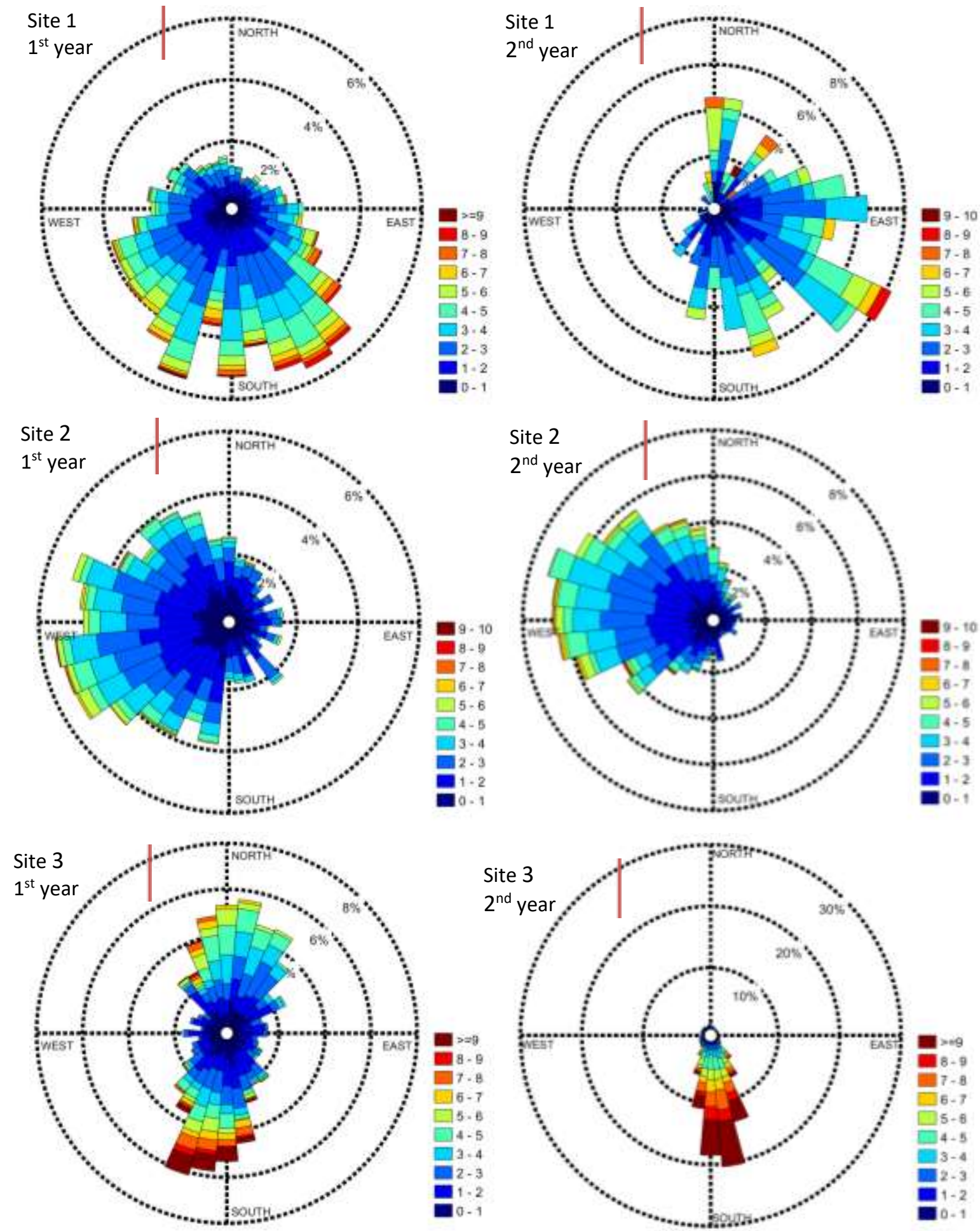

\subsection{Sediment samples}

The highest content of MBT, DBT and TBT were found at site 1 which receives effluent waters including particles from the WWTP (Fig. 3). At site 1 the TBT content increased with the core depth $\left(1.4 \mu \mathrm{g} \mathrm{kg}^{-1}\right.$, 
268 the release of TBT has diminished in recent years. According to simultaneous study OTCs are released 269 from the WWTP since the effluent waters contained 0.2-2.0 $\mathrm{ng} \mathrm{L}^{-1} \mathrm{TBT}, 1-18 \mathrm{ng} \mathrm{L}^{-1} \mathrm{DBT}$ and 2.4-51 ng L$270{ }^{1}$ MBT (Ahkola et al. 2016).

271 Sediment samples at sites 5 and 3, located at deep parts of the lake and downstream from the WWTP, had 272 higher concentrations of BTCs than the reference site 6 (Fig. 3). This indicates that at least WWTP 273 originated particles drift mainly downstream and those sites can act as sedimentation sinks. The site 6 is 274 the main waterway and boat traffic may disturb the lake bottom, cause resuspension and hinder the 275 sedimentation process. Site 2 is in the shallow part of the lake away from the main waterway and due to 276 currencies receives some effluent from the WWTP.

277 In Lake Päijänne BTCs have been previously measured in surface sediment from the study area near sites 2781 and between sites 3 and 4 . The samples at depth of $2-3 \mathrm{~cm}$ and the contents for MBT, DBT and TBT were $2798.6 \mu \mathrm{g} \mathrm{kg}^{-1}, 1.8 \mu \mathrm{g} \mathrm{kg}^{-1}$ and $0.9 \mu \mathrm{g} \mathrm{kg}^{-1}$, respectively (Mannio et al. 2011). These results were somewhat 280 lower than the ones observed in this study.

281 As there is no classification system for contaminated sediments in Finland, the concentrations can be 282 compared with Norwegian and Swedish EQS values which are for TBT $0.002 \mu \mathrm{g} \mathrm{kg}^{-1}$ and $1.6 \mu \mathrm{g} \mathrm{kg}^{-1}$, 283 respectively (Olsen et al. 2019). The Norwegian EQS values were exceeded at all sampling sites but the 284 Swedish EQS only at site 1 on core depths 1-3 and 3-5. This suggests that the sediment in the study area is 285 contaminated by TBT. 


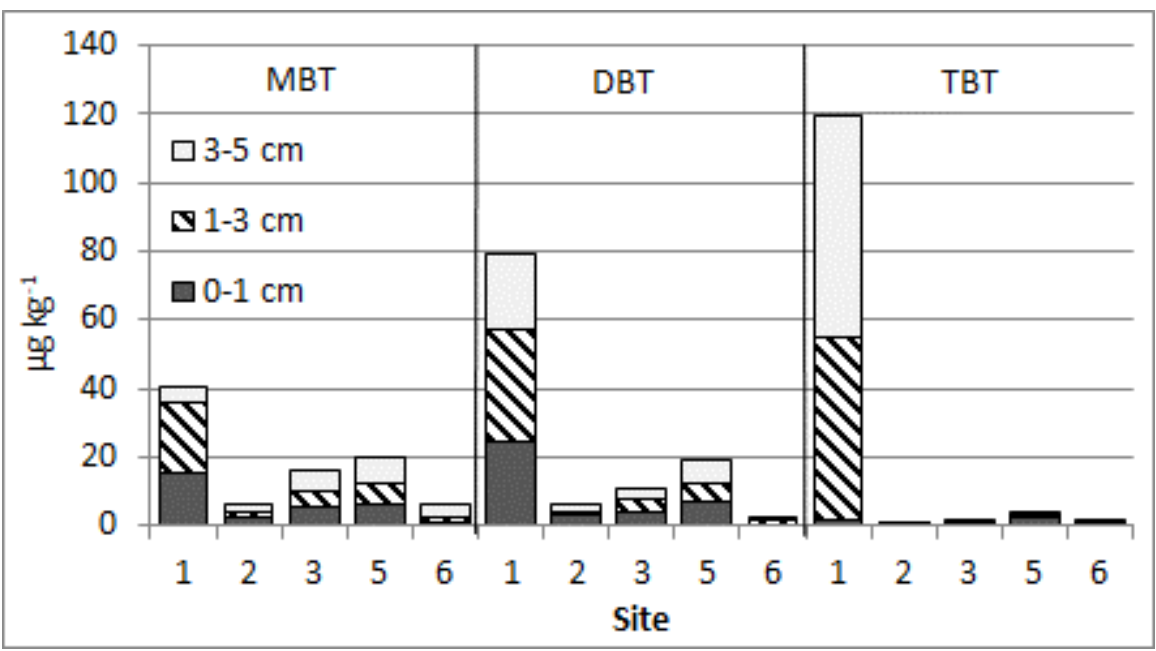

Fig. 3. Concentration of BTCs in sediment samples.

\subsection{Sedimentation traps}

\subsubsection{Settling particles in sedimentation traps}

292 The highest amount of particles settled into sedimentation traps (as dw) was measured at site 1 which receives the effluent waters directly from the WWTP (Fig. 4). At reference site 6 the amounts of settling particles in $1^{\text {st }}$ study year were higher than at sites $3-5$ being twice as high than in the $2^{\text {nd }}$ year. This implies that particles drift upstream from the study area to the site 6 . In $2^{\text {nd }}$ year the highest amount of settling particles was measured at site 2 which is located at shallow part of the lake and has lots of aquatic vegetation. Due to currents site 2 also receives effluents from WWTP which can bring particles to the area.

298 The amount of particles was the lowest at site 4 which is located furthest from the WWTP.

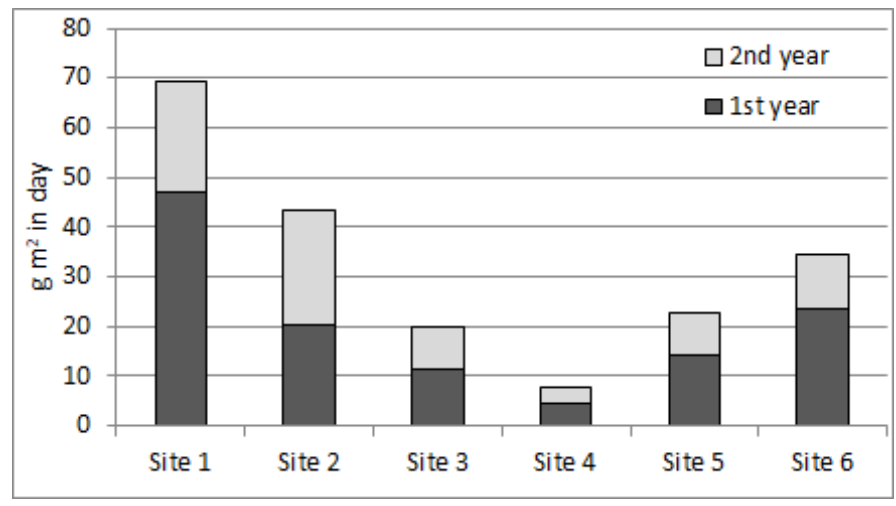

299 Fig. 4. Amount of settling particles in sedimentation traps. 


\subsubsection{BTC concentrations in settling particles of sedimentation traps}

301 The highest BTC concentrations (as dw) were measured at the outlet of WWTP (site 1, Fig. 5). The high 302 amount of settling particles found at sites 2 and 6 did not increase the BTC concentration (Fig. 4 and 5). 303 Apparent connection between the particle amount and the BTC concentration in settling particles was not 304 observed. The BTC concentrations were slightly higher in $1^{\text {st }}$ year at all sites except for site 6 . However, 305 the differences are negligible. The relative abundance of MBT, DBT and TBT at site 1 differed from the 306 ones detected at the other sampling sites as at site 1 the DBT dominated whereas MBT was the prevailing BTC at the rest of the sites (Fig. 5). The high particle bound BTC release from the WWTP in the $1^{\text {st }}$ year 308 can derive from the pipe broke which released activated sludge to effluent and further to the watercourse.

309 This accident is further discussed in Chapter 3.6.
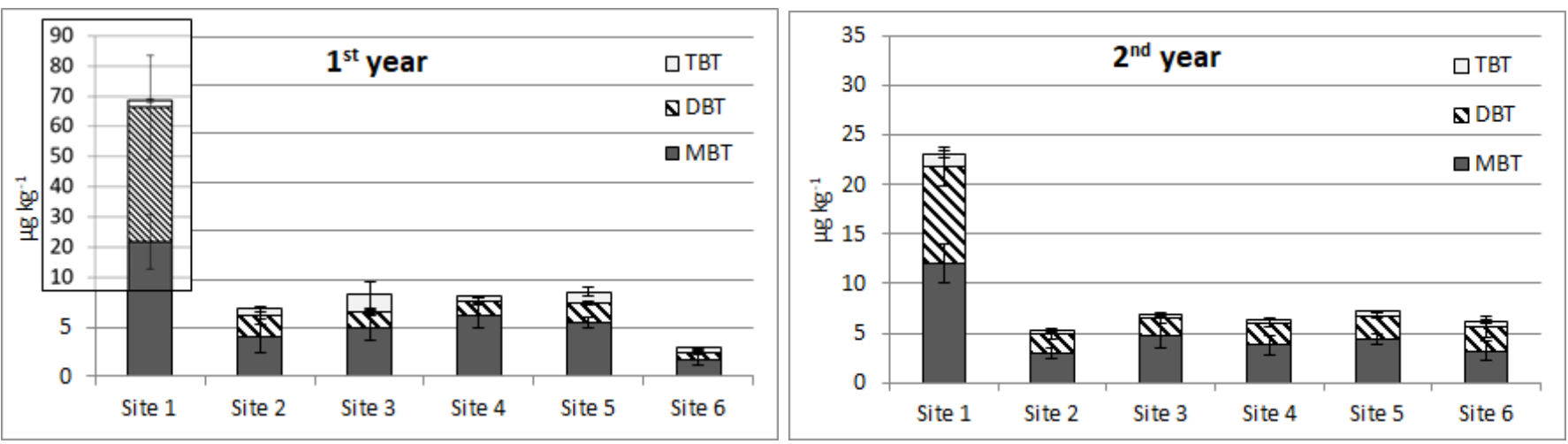

310 Fig. 5. Average of MBT, DBT and TBT concentration in settling particles. Notice the scaling of the $1^{\text {st }}$ 311 years chart.

\subsection{Passive sampling}

313 The concentrations of BTCs observed with passive sampling were not clearly higher at WWTP outflow 314 (site 1) than at other sites (Fig. 6). One reason is that the BTCs are bound to particles present in effluent waters and are not available for passive samplers. Higher BTC concentrations were detected in all 
316 Chemcatcher passive samplers deployed in $1^{\text {st }}$ year than in $2^{\text {nd }}$ year. According to the results the dissolved

317 fraction of BTCs remained quite stable during each study year.
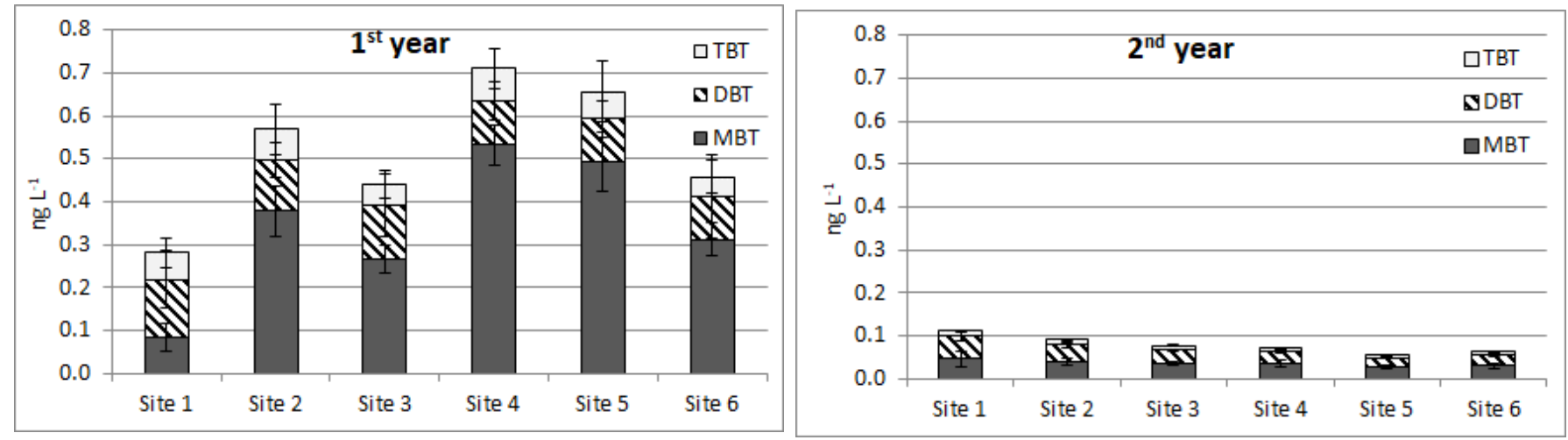

318 Fig. 6. Average of MBT, DBT and TBT concentrations in Chemcatcher passive samplers.

\subsection{Grab sampling}

The concentration of BTCs in grab water samples was expected to be low and only concentration which exceeded LOD were included in the calculations. The MAC-EQS of TBT was exceeded only once in one grab sample taken during the first study year (Table S2). As the LOD of TBT was the same as AA-EQS it was exceeded when observed. According to literature there are not many studies concerning determination of BTCs in inland waters, possibly due to analytical restrictions deriving from the low concentrations. According to study of Aguilar-Martinez et al. (2011) the concentration of TBT in inland waters (Lake San Juan, Spain) remained below LOD both in grab and passive sampling, TBT LODs for grab samples was 9 $\mathrm{ng} \mathrm{\textrm {L } ^ { - 1 }}$ and for passive samplers $1.2 \mathrm{ng} \mathrm{L}^{-1}$. MBT was detected in grab samples $\left(4.0 \mathrm{ng} \mathrm{L}^{-1}\right)$ and passive samplers $\left(9.1 \mathrm{ng} \mathrm{L}^{-1}\right)$ as well as DBT $\left(9.0 \mathrm{ng} \mathrm{L}^{-1}\right)$ and $\left(2.6 \mathrm{ng} \mathrm{L}^{-1}\right)$, respectively. In Finland, BTCs have been studied in wastewater where MBT and DBT were detected in concentrations of 4-20 ng/L and 1.6-5.6 ng/L, respectively (Mannio et al. 2011). However, the TBT concentrations remained below the detection limit (0.5 ng/L). Also Vieno (2014) measured TBT from 60 WWTP effluents and detected it at four samples with average concentration of $0.22 \mathrm{ng} / \mathrm{L}$. As with passive sampling data the MBT and DBT concentrations were considerably higher in $1^{\text {st }}$ year than in the $2^{\text {nd }}$ year (Fig. 6 and 7). In TBT concentrations this was observed as well but it was not that evident. However, the concentrations between these two sampling techniques are significant as grab samples include both dissolved and particle bound fraction. All in all, the 
337 lower in the $2^{\text {nd }}$ year.
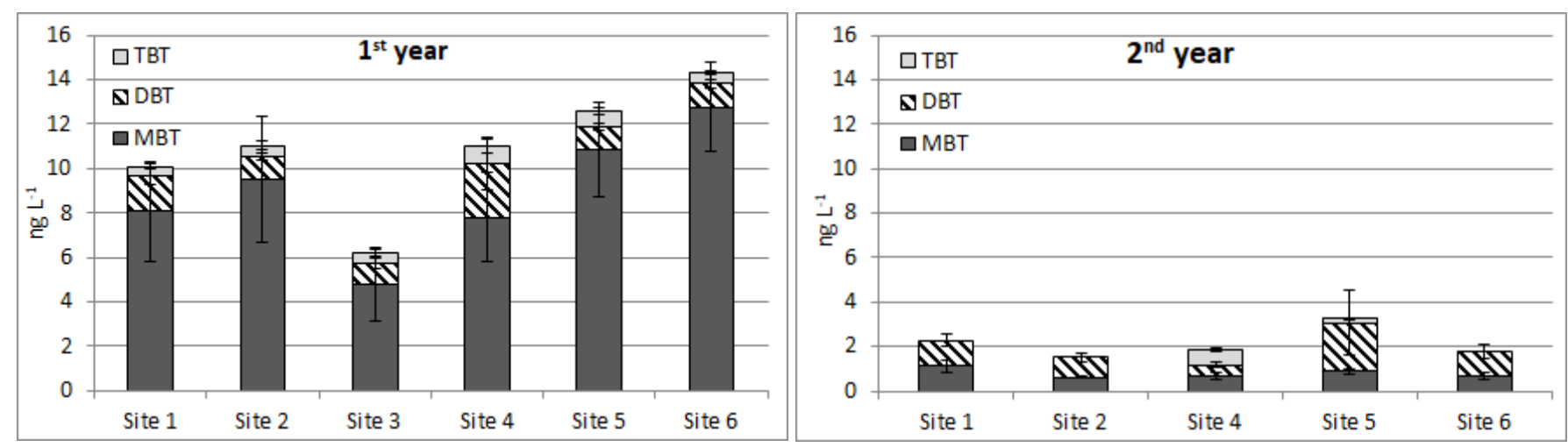

Fig. 7. Average BTC concentrations in grab water samples.

\subsection{Summary of the sampling techniques}

The passive sampling technique had the lowest LOD expressed as MDL for 2 weeks deployment than grab sampling (Table 1). MBT was detected in $29-87 \%$ and DBT in $29-55 \%$ of grab samples (Table 3 ). With passive sampling the detection percentage for MBT and DBT was 96-100\% and with sedimentation traps $67-79 \%$. However, TBT was detected only in $4-24 \%$ of the grab samples when the detection with passive samplers was $90-94 \%$ and with sedimentation traps $50-52 \%$. When the concentration of TBT in grab samples remained below LOD $\left(0.2 \mathrm{ng} \mathrm{L}^{-1}\right)$ it does not necessarily mean that the TBT is not present in aquatic environment. Passive samplers collect BTCs for longer time period and if BTCs are present at even trace concentrations they will be enriched to the sampler. As TBT is detected more often in passive samplers than in grab samples the samplers were able to detect the concentrations which in grab samples would remain undetected. This suggests that with passive sampling the presence of TBT in surface waters can be detected more reliably than with grab sampling.

Table 3. Detection of BTCs with different sampling techniques.

\begin{tabular}{l|c|c|c|c|c|c}
\hline \multirow{2}{*}{$\begin{array}{l}\text { Sampling } \\
\text { technique }\end{array}$} & \multicolumn{2}{c|}{$\begin{array}{c}\text { \% of samples in which } \\
\text { MBT was detected }\end{array}$} & $\begin{array}{c}\text { \% of samples in which } \\
\text { DBT was detected }\end{array}$ & \multicolumn{2}{c}{$\begin{array}{c}\text { \% of samples in which } \\
\text { TBT was detected }\end{array}$} \\
\cline { 2 - 7 } & $\mathbf{1}^{\text {st }}$ year & $\mathbf{2}^{\text {nd }}$ year & $\begin{array}{c}\mathbf{1}^{\text {st }} \\
\text { year }\end{array}$ & $\mathbf{2}^{\text {nd }}$ year & $\mathbf{1}^{\text {st }}$ year & $\mathbf{2}^{\text {nd }}$ year \\
\hline $\begin{array}{l}\text { Sedimentation } \\
\text { traps }\end{array}$ & 79 & 79 & 67 & 67 & 52 & 50 \\
\hline Passive sampling & 96 & 100 & 98 & 100 & 94 & 90 \\
\hline Grab sampling & 87 & 29 & 55 & 29 & 24 & 4 \\
\hline
\end{tabular}


353 The pipe broke at WWTP released activated sludge with effluent waters to Lake Päijänne and site 1 . The 354 leak was noticed in in the beginning of the $1^{\text {st }}$ years sampling campaign on $31^{\text {st }}$ May and was fixed at $7^{\text {th }}$ 355 June so it took place during the first passive sampler and sedimentation trap deployment. The grab sampling was conducted 8 days after the leak $\left(14^{\text {th }}\right.$ June $)$ and this leak was not noticed, only slightly elevated MBT concentrations were detected. Two weeks deployment of passive samplers during the leak $\left(30^{\text {th }}\right.$ May- $14^{\text {th }}$ June) implied elevated concentrations of dissolved BTC and the concentrations decreased in the next sampling occasion. However, the concentrations increased again as the deployment trials continued. In settling particles data, the sludge release was discovered as high concentrations, which in case of MBT and DBT diminished as the trials continued. As the BTCs are released with activated sludge their detection in settling particles is more probable than with grab or passive samples.
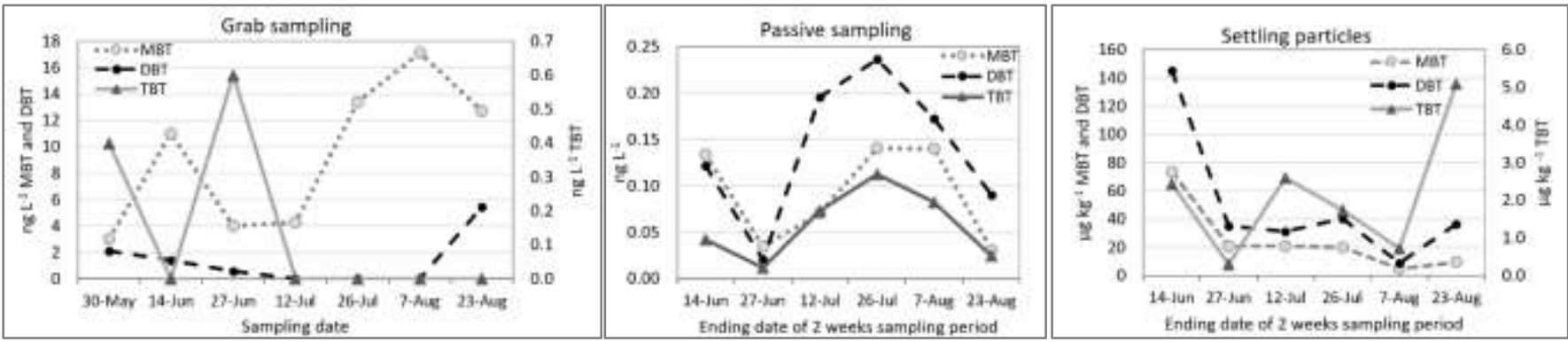

Fig. 8. Concentration of BTCs at site 1 during the pipe broke at WWTP. Notice that the x-axis of passive samplers and sedimented particles describe the retrieval date after two weeks deployment but in grab sampling the exact sampling date. 


\subsection{Computational estimation of sources of BTC}

The computational modelling results imply that the effluent waters do not reach site 6 in conditions prevailing in the study area (Fig. 9). Positive values would indicate that the BTCs spread from site 1 upstream to site 6, but as the modelling results presented negative values (Fig. 9), the discharge spreads downstream. The grab water sampling and Chemcatcher passive sampling results suggest that site 6 has rather high content of dissolved BTCs as they are detected with those techniques. In settled particles collected with sedimentation traps the BTC contents were low which also implies that BTCs were in their dissolved form. However, the modelling reveals that these particles do not originate from the WWTP.

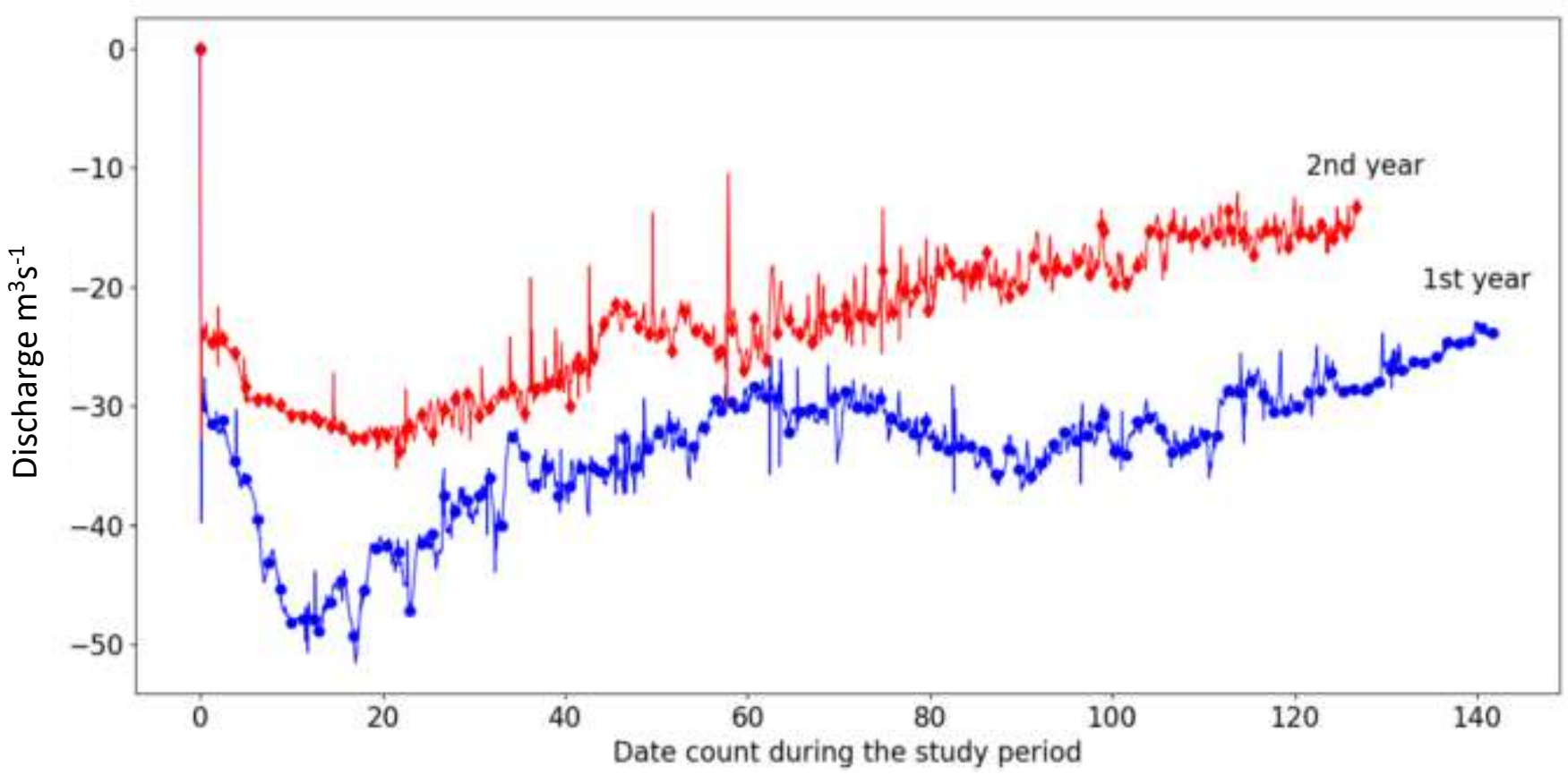

Fig. 9. Modelling the spreading of BTC particles from the site 1 (WWTP). Negative values indicate discharge downstream towards site 3 and positive values mean discharge upstream towards site 6 . According to calculations the BTCs detected at site 1 are most apparently originated from WWTP (Table 4). This is obvious as site 1 receives the WWTP effluents. The next sites assumable receiving BTCs from WWTP are 5, 2 and 3 but their order varies between the study years e.g. the prevailing currents (Fig. 2). The most unlikely sites to have particles originating from WWTP are sites 4 and 6 which also supports the assumption that BTCs found at site 6 are from another source than the WWTP. 
Table 4. The estimated probability class that the detected BTCs originate from WWTP

\begin{tabular}{c|c|c}
\hline Probability & $\mathbf{1}^{\text {st }}$ year & $\mathbf{2}^{\text {nd }}$ year \\
\hline \multirow{3}{*}{ High } & Site 1 & Site 1 \\
\cline { 2 - 3 } Medium & Site 3 & Site 5 \\
\cline { 2 - 3 } Low & Site 5 & Site 2 \\
\cline { 2 - 3 } & Site 2 & Site 3 \\
\cline { 2 - 3 } & Site 4 & Site 4 \\
\cline { 2 - 3 } & Site 6 & Site 6 \\
\hline
\end{tabular}

The difference between the study years was also observed in the transportation simulations. Probability that BTC is discharged from WWTP and travels to location $\mathrm{i}\left(\mathrm{P}_{\mathrm{i}}\right)$ was systematically higher in the $1^{\text {st }}$ study year than the $2^{\text {nd }}$ one. This appeared regardless of the simulation method used, mimicking passive sampling (continuous release of BTCs during the two weeks period) or grab sampling (same amount of BTCs released at once in every two weeks). The simulation results show that it is nearly impossible that the observed BTCs would have come from the upstream site 6 . When comparing the ratios of the most likely and most unlikely locations $\mathrm{R}_{\mathrm{i}}=\max \left(\mathrm{P}_{\mathrm{i}}\right) / \min \left(\mathrm{P}_{\mathrm{i}}\right)$ we notice deviation between the study years and apparent difference between the simulation methods (Table 5). It is expected that if number of BTCs released during the two weeks' time period (passive sampling) increase, the ratio of most likely and most unlikely locations would increase as well. However, the ratios $\mathrm{R}_{\mathrm{i}}$ were systematically lower for simulation mimicking passive sampling than the one mimicking grab sampling. This means that the most likely and most unlikely locations differ more when mimicking grab sampling release and suggests that timing of instant grab sampling plays more significant role in detecting pollutants as expected.

Table 5. Ratios $\left(\mathrm{R}_{\mathrm{i}}\right)$ of maximum and minimum probabilities for TBT.

\begin{tabular}{c|c|c|c|c|c}
\hline Release type & Year & Site 2 & Site 3 & Site 4 & Site 5 \\
\hline \multirow{2}{*}{ Passive sampling } & $1^{\text {st }}$ year & 70 & 41 & 5.0 & 17 \\
\cline { 2 - 6 } & $2^{\text {nd }}$ year & 1.7 & 11 & 31 & 4.3 \\
\hline \multirow{2}{*}{ Grab sampling } & $1^{\text {st }}$ year & 2100 & 200 & 500 & 71 \\
\cline { 2 - 6 } & $2^{\text {nd }}$ year & 1200 & 30 & 61 & 23 \\
\hline
\end{tabular}

\subsection{Extreme value analysis}

Determining BTCs from grab water samples require analytical techniques with low quantification levels.

By grab sampling BTCs are seldom detected in surface waters despite they are present at trace concentrations. Only the high peak concentrations of the underlying continuous time series are observed. 
406 statistical analysis does not apply i.e., statistical test (such as Student t-test) assuming normality, fails. 407 However, there is an own line of statistics called "extreme value theory" which can be applied to study the 408 behaviour and statistics of extreme values.

409 We perform extreme value analysis using peak-over threshold approach (POT-analysis). It is well known 410 fact that excess $x_{\mathrm{j}}$ i.e., value $\left(y_{i}\right)$-threshold $(u)$ is distributed as generalized pareto distribution (GPD) (Bezak 411 et al. 2014):

$412 G_{\varepsilon}(x)=\left\{\begin{array}{c}1-\left(1-\varepsilon \frac{x}{\beta}\right)^{\frac{1}{\varepsilon}}, \varepsilon \neq 0 \\ 1-e^{-x / \beta}, \varepsilon=0\end{array}\right.$

413 where $\varepsilon$ is shape parameter and $\beta$ is scale parameter. The range of $x$ is $0 \leq x<\infty$ for $\varepsilon \leq 0$ and $0 \leq x \leq$ $414 \beta / \varepsilon$ for $\varepsilon>0$. When $\varepsilon>-1$ expected value for excess $x$ is

$415 \quad \mathbb{E}(x)=\frac{\beta}{1+\varepsilon}$

416 and variance

$417 \quad \sigma^{2}=\frac{\beta^{2}}{(1+\varepsilon)^{2}(1+2 \varepsilon)}$

418 that is finite only when $\varepsilon>-(1 / 2)$. If GPD is valid for excess values over threshold $u_{0}$ it is valid also for 419 other excess values if $u>u_{0}$. Expectation value function for the excess is thus

$420 \quad e(u)=\frac{\beta_{0}}{1-\varepsilon}+\frac{\varepsilon}{1-\varepsilon} u$ 
Expectation value function for the excess as a function of threshold is thus linear when $u>u_{0}$. This provides one visual approach to select the threshold value $u$. In brief, after choosing a good threshold value $u$ the dependency between $u$ and empirical estimation of expected value seems linear. Determination of correct or even satisfactory value for $u_{0}$ is not trivial or easy to do (Roth et al. 2016). From Fig. 10 we observe that even after suitable $u_{0}$ linear behaviour does not necessarily apply. In tail only few values exceeding thresholds cause large variation for graphs. Thus, we cannot be sure that the selected threshold
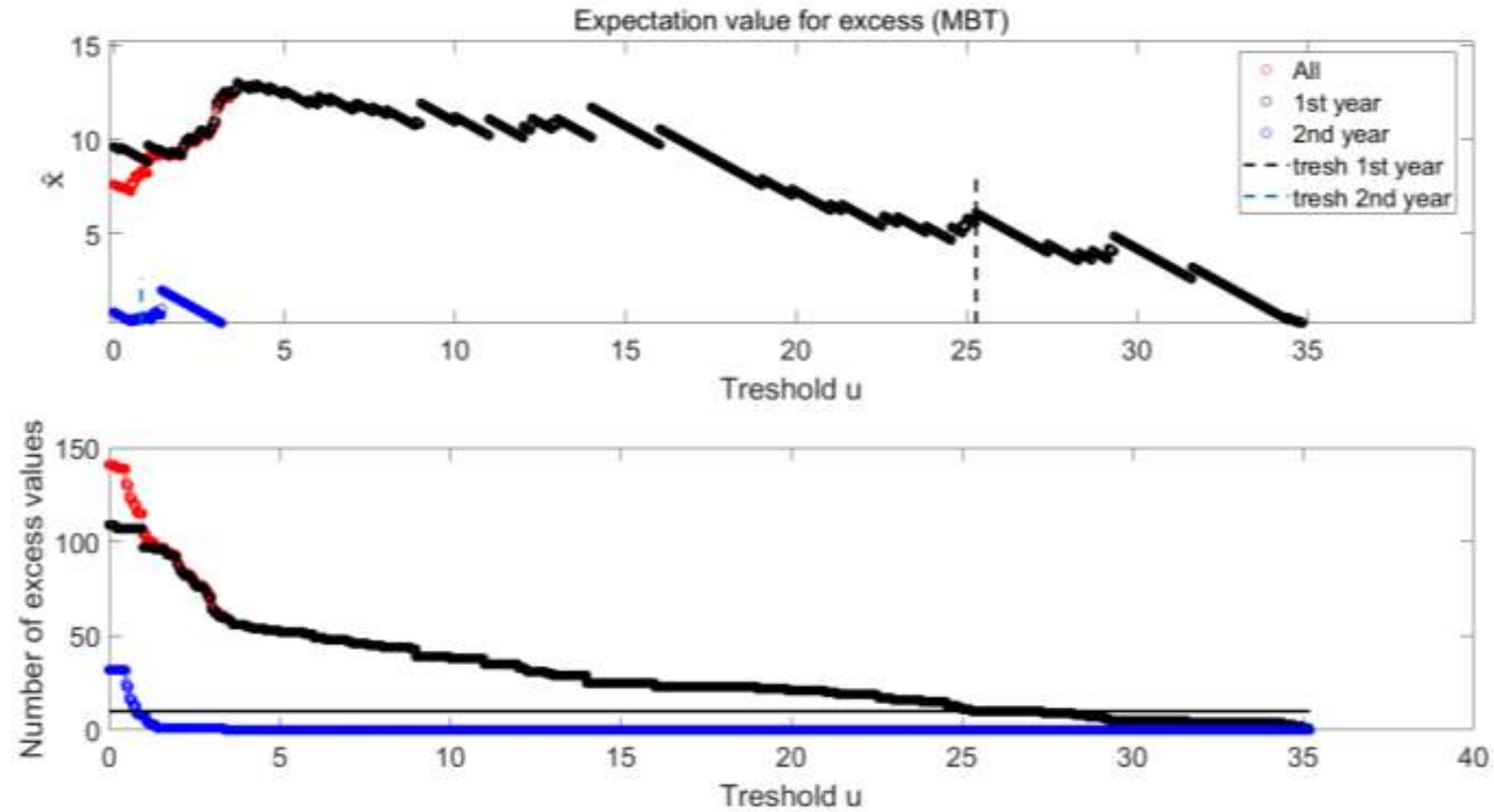

$427 \quad$ values are suitable ones.

428 Fig. 10. Expectation value function for MBT for $1^{\text {st }}$ and $2^{\text {nd }}$ (upper) study year and corresponding number 429 of those exceeded values e and function of threshold $\mathrm{u}$ (lower).

430 POT analysis can be made regardless of the measuring strategy. The results are presented in Tables 6-8. At 431 first, we will examine the processes that BTCs undergo when considering different sampling techniques. 432 The biggest difference is that grab sampling is instantaneous sampling technique, while passive sampling 433 and sedimentation traps are integrative sampling methods. Processes effecting the accumulation of BTCs 434 to the samplers and to the settled particles may help in the interpretation of differing results. For passive 435 samplers there are physical limits how much material can be accumulated into sampler which sets limit to 
the sampling capacity. Furthermore, since samplers are not selective the sampler's capacity can be taken by some unknown chemical which is not studied.

We use method suggested by Choulakian and Stephens (2001) i.e., goodness of fit -approach where GPD and empirical cumulative distribution function (CDF) are compared statistically. Estimations for shape $\varepsilon$ and scale $\beta$ parameters were found by maximum likelihood method and here we use Cramér-von Mises statistic $\mathrm{W}^{2}$ and the Anderson-Darling statistic $\mathrm{A}^{2}$. Acceptable p-value for good fit is 0.1 but as appears in Tables 6-8 all presented parameters produced higher p-values than 0.1 which makes them plausible.

Threshold values u for concentrations, after which measurement are considered as extreme, are close to the LOD especially for TBT (Tables 6-8). For $2^{\text {nd }}$ study year's threshold values for grab and passive samplers' results are smaller than for the $1^{\text {st }}$ study year. Generally short-tailed distributions $(\varepsilon>0)$ are especially interesting since they indicate maximum possible value for observation. Based on shape parameters $\varepsilon$, presented in Tables 6-7, this is quite common. For grab samples the distributions for MBT and TBT in $1^{\text {st }}$ year were short-tailed ones. From Table 7 we see that for MBT and DBT value $\varepsilon>0$ in the $1^{\text {st }}$ year while for TBT $\varepsilon>0$ in the $2^{\text {nd }}$ year. Only for BTC measured from settled particles in sedimentation traps were systematically $\varepsilon<0$. Furthermore, different BTCs can be short or long tailed in same year. When considering MBT from grab samples the parameter describing the distributions of exceedances $\beta$ deviates greatly between the $1^{\text {st }}$ and the $2^{\text {nd }}$ year (Table 6). None of the values observed in $2^{\text {nd }}$ year even exceeded the threshold of the $1^{\text {st }}$ year. For DBT the obtained values were much closer to each other. For TBT the number of observed values in the $2^{\text {nd }}$ year were so small that analysis was not reasonable.

For grab sampling even long-tailed distribution $(\varepsilon<0)$ values were $\varepsilon>-0.5$ which means that distributions have limited variance (Table 6). For BTC determined from passive samplers or settled particles in sedimentation traps this does not apply anymore (Tables 7 and 8). One distribution for BTC gathered with sedimentation traps is so long-tailed that even expected value u cannot be determined (Table 8).

If considering number of grab sampling observations that were higher than threshold value $u$, the MBT had the lowest percentage (51\% $1^{\text {st }}$ year, $56 \% 2^{\text {nd }}$ year) while DBT and TBT had percentages over 70\% (Table 
6). This indicates that values of DBT and TBT indeed are extreme values. For passive sampling the

462 percentage of extreme values were significantly lower. This is expected since passive sampling concentrates

463 the low concentrations to detectable level and the peak concentrations integrates to TWA concentration.

464 For MBT about $60 \%$, TBT about $37 \%$ while for DBT the percentages differed lot between years being $44 \%$

465 and $81 \%$. For BTC determined with sedimentation trap sampling smallest percentage value was $69 \%$.

466 The results suggest that grab sampling and sedimentation trap sampling results contain more extreme peak

467 values than passive sampling. Deviation between threshold values u and LOD values indicates applicability

468 and usability of the sampling method. If the deviation is small majority of observed values are extreme

469 values and the mean or median of underlying concentration timeseries is very low, and vice versa. Extreme

470 value analysis can therefore be used to estimate actual level of average concentration of BTC.

471 Table 6. Shape and scale parameters for grab sampling from POT analysis.

\begin{tabular}{c|c|c|c|c|c|c|c|c}
\hline Compound & Year & $\boldsymbol{\varepsilon}$ & $\boldsymbol{\beta}$ & $\mathbf{u}$ & $\mathbf{N}_{\text {tot }}$ & $\mathbf{N}_{\mathrm{ab}}$ & $\mathbf{W}^{\mathbf{2}}$ & $\mathbf{A}^{\mathbf{2}}$ \\
\hline MBT & $\mathbf{1}^{\text {st }}$ year & 0.7465 & 24.1836 & 3.621 & 109 & $56(51 \%)$ & $0.1554(\mathrm{p}>0.1)$ & $0.8331(\mathrm{p}>0.1)$ \\
\hline MBT & $\mathbf{2}^{\text {nd }}$ year & -0.2386 & 0.3481 & 0.6 & 32 & $18(56 \%)$ & $0.0584(\mathrm{p}>0.25)$ & $0.4450(p>0.25)$ \\
\hline DBT & $\mathbf{1}^{\text {st }}$ year & -0.3654 & 0.66873 & 0.60 & 71 & $51(72 \%)$ & $0.0735(\mathrm{p}>0.25)$ & $0.6124(p>0.1)$ \\
\hline DBT & $\mathbf{2}^{\text {nd }}$ year & -0.4247 & 0.4313 & 0.4966 & 30 & $26(87 \%)$ & $0.03(\mathrm{p}>0.5)$ & $0.3658(p>0.25)$ \\
\hline TBT & $\mathbf{1}^{\text {st }}$ year & 0.2755 & 0.5823 & 0.2 & 30 & $23(77 \%)$ & $0.0793(p>0.25)$ & $0.5994(p>0.25)$ \\
\hline TBT & $\mathbf{2}^{\text {nd }}$ year & & & & 4 & 1 & & \\
\hline
\end{tabular}

472 Table 7. Shape and scale parameters for passive sampling from POT analysis.

\begin{tabular}{c|l|l|l|l|l|l|l|l}
\hline Compound & \multicolumn{1}{c|}{ Year } & \multicolumn{1}{c|}{$\boldsymbol{\varepsilon}$} & $\boldsymbol{\beta}$ & \multicolumn{1}{c|}{$\mathbf{u}$} & $\mathbf{N}_{\text {tot }}$ & $\mathbf{N}_{\text {ab }}$ & $\mathbf{W}^{\mathbf{2}}$ & $\mathbf{A}^{\mathbf{2}}$ \\
\hline MBT & $\mathbf{1}^{\text {st }}$ year & 0.0689 & 0.0862 & 0.05 & 37 & $22(59 \%)$ & $0.0144(p>0.5)$ & $0.1389(p>0.5)$ \\
\hline MBT & $\mathbf{2}^{\text {nd }}$ year & -0.5290 & 0.0096 & 0.02681 & 42 & $26(62 \%)$ & $0.0379(p>0.5)$ & $0.3026(p>0.5)$ \\
\hline DBT & $\mathbf{1}^{\text {st }}$ year & 0.2728 & 0.0978 & 0.1224 & 39 & $17(44 \%)$ & $0.1238(p>0.1)$ & $0.7183(p>0.1)$ \\
\hline DBT & $\mathbf{2}^{\text {nd }}$ year & -0.3172 & 0.0098 & 0.02302 & 42 & $34(81 \%)$ & $0.0448(p>0.5)$ & $0.2969(p>0.5)$ \\
\hline TBT & $\mathbf{1}^{\text {st }}$ year & -0.5557 & 0.0161 & 0.08 & 39 & $15(38 \%)$ & $0.0275(p>0.5)$ & $0.1961(p>0.5)$ \\
\hline TBT & $\mathbf{2}^{\text {nd }}$ year & 0.3023 & 0.0058 & 0.009542 & 38 & $14(37 \%)$ & $0.0538(p>0.5)$ & $0.5374(p>0.25)$ \\
\hline
\end{tabular}

473 Table 8. Shape and scale parameters for sedimentation trap sampling from POT analysis.

\begin{tabular}{c|l|c|c|l|l|l|l|l}
\hline Compound & Year & $\boldsymbol{\varepsilon}$ & $\boldsymbol{\beta}$ & $\mathbf{u}$ & $\mathbf{N}_{\text {tot }}$ & \multicolumn{1}{|c}{$\mathbf{N}_{\mathrm{ab}}$} & $\mathbf{W}^{\mathbf{2}}$ & $\mathbf{A}^{\mathbf{2}}$ \\
\hline MBT & $\mathbf{1}^{\text {st }}$ year & -0.0831 & 3.4035 & 0 & 38 & $38(100 \%)$ & $0.0590(\mathrm{p}>0.5)$ & $0.5060(\mathrm{p}>0.25)$ \\
\hline MBT & $\mathbf{2}^{\text {nd }}$ year & -0.2017 & 2.9002 & 1.976 & 33 & $32(97 \%)$ & $0.0295(\mathrm{p}>0.5)$ & $0.1958(\mathrm{p}>0.5)$ \\
\hline DBT & $\mathbf{1}^{\text {st }}$ year & -1.5084 & 0.8597 & 1.214 & 32 & $22(69 \%)$ & $0.0393(p>0.5)$ & $0.3130(p>0.5)$ \\
\hline DBT & $\mathbf{2}^{\text {nd }}$ year & -0.3906 & 1.9096 & 1.04 & 28 & $26(93 \%)$ & $0.0383(p>0.5)$ & $0.3756(p>0.25)$ \\
\hline TBT & $\mathbf{1}^{\text {st }}$ year & -0.6912 & 0.2796 & 0.23 & 25 & $20(80 \%)$ & $0.0268(p>0.5)$ & $0.2551(p>0.5)$ \\
\hline TBT & $\mathbf{2}^{\text {nd }}$ year & -0.4894 & 0.2692 & 0.2703 & 21 & $19(90 \%)$ & $0.0326(p>0.5)$ & $0.2276(p>0.5)$ \\
\hline
\end{tabular}




\section{Conclusions}

In this study the occurrence of BTCs as total-, dissolved or particle bound fraction was monitored with grab water-, passive -, and sedimentation trap sampling for two years from May to September. The study years were hydrologically different which was observed as higher dissolved BTC concentrations during the first year. Still their concentration in particle bound fraction remained the same. The hydrological differences can be observed at site 3 where varying water current direction mix the water column more efficiently during the $2^{\text {nd }}$ study year than in the $1^{\text {st }}$ year. Also, the currents from site 1 , which releases effluent from the WWTP, towards site 2 are higher in the $2^{\text {nd }}$ study year.

In this study even the trace concentrations of BTCs were detected due to enhanced sensitivity of the analysing and sampling techniques. This enables more accurate estimation of concentrations and to assess the condition of watercourse more precisely. As AA-EQS of TBT was exceeded several times during the $1^{\text {st }}$ study year the lake does not seem to be in good chemical conditions, when considering TBT. However, this assumption is not supported when considering the $2^{\text {nd }}$ study year when only few exceedings were observed.

To assess if the measured BTC concentrations prevail at the study area instead of being just high instant peak concentrations, we performed innovative statistical extreme value analysis. The results suggest that grab sampling and sedimentation trap sampling results contain more extreme peak values than passive sampling. This proposes that the reliability of grab sampling is the lowest from the assessed techniques when the presence of BTCs are studied.

The assumption that BTCs are released only from WWTP was not valid as high concentrations were detected from sampling site 6 located upstream of WWTP which was at the beginning of this study considered as reference site for determining background concentration. By computational modelling and back tracking simulations we were able to detect the possible sources of BTCs and found that they can come upstream of the sampling area where is summer houses, boats, piers and wood processing industry. Hence WWTP cannot be considered as the only source of BTCs. 


\section{Supplementary tables:}

518 Table S1. Concentrations of BTCs in sediment samples.

519 Table S2. Concentrations of BTCs in grab samples during the 1st study year.

520 Table S3. Concentrations of BTCs in grab samples during the 2nd study year.

521 Table S4. TWA concentrations of BTCs in passive samplers during the 1st study year.

522 Table S5. TWA concentrations of BTCs in passive samplers during the 2nd study year.

523 Table S6. Concentrations of BTCs in settled particles during the 1st study year.

524 Table S7. Concentrations of BTCs in settled particles during the 2nd study year. 


\section{Declarations}

Ethics approval and consent to participate

529 Not applicable

\section{Consent for publication}

531 Not applicable.

532 Availability of data and materials

533 All data generated or analysed during this study are included in this published article [and its supplementary

534 information files].

535 Competing interests

536 The authors declare that they have no competing interests.

$537 \quad$ Funding

538 This study was supported by European Regional Development Fund, Maj and Tor Nessling foundation and 539 Maa- ja vesitekniikan tuki ry.

540 Authors' contributions

541 Heidi Ahkola was the main contributor in writing the manuscript. HA participated in planning of field trials 542 and taking the passive, sediment and water samples.

543 Janne Juntunen performed hydrological data handling, computational estimation of BTC sources and 544 extreme value analysis. JJ participated in planning of field trials and taking the passive, sediment and water 545 samples.

546 Kirsti Krogerus performed the planning of field trials and taking the passive, sediment and water samples.

547 Timo Huttula performed the planning of field trials and taking the passive, sediment and water samples.

548 All authors read and approved the final manuscript.

549 Acknowledgements

550 The help of M.Sc. Petri Nieminen and M.Sc. Tino Hovinen for conducting the passive sampling trials is 551 greatly appreciated. The effort of B.Sc. Saara Haapala, M.Sc. Tiina Virtanen, Ms. Rauni Kauppinen, Mr. 552 Samuli Pietiläinen and Mr. Aleksi Tiusanen on the sample treatment is highly appreciated. 


\section{References}

554 Aguilar-Martinez R, Greenwood R, Mills GA, Vrana B, Palacios-Corvillo MA, Gomez-Gomez MM 555 (2008a) Assessment of Chemcatcher passive sampler for the monitoring of inorganic mercury and 556 organotin compounds in water. Int $\mathrm{J}$ Environ an $\mathrm{Ch}$ 88(2):75-90. 557 https://doi.org/10.1080/03067310701461870

558 Aguilar-Martinez R, Palacios-Corvillo MA, Greenwood R, Mills GA, Vrana B, Gomez-Gomez MM 559 (2008b) Calibration and use of the Chemcatcher (R) passive sampler for monitoring organotin compounds 560 in water. Anal Chim Acta 618(2):157-167. https://doi.org/10.1016/j.aca.2008.04.052

Aguilar-Martinez R, Gomez-Gomez MM, Palacios-Corvillo MA (2011) Mercury and organotin 562 compounds monitoring in fresh and marine waters across Europe by Chemcatcher passive sampler. Int J 563 Environ an Ch 91(11):1100-1116. https://doi.org/10.1080/03067310903199534

564 Ahkola H, Herve S, Knuutinen J (2013) Overview of passive Chemcatcher sampling with SPE pretreatment 565 suitable for the analysis of NPEOs and NPs. Environ Sci Pollut R 20(3):1207-1218. 566 https://doi.org/10.1007/s11356-012-1153-0

Ahkola H, Herve S, Knuutinen J (2014) Study of different Chemcatcher configurations in the monitoring of nonylphenol ethoxylates and nonylphenol in aquatic environment. Environ Sci Pollut R 21(15):91829192. https://doi.org/10.1007/s11356-014-2828-5

Ahkola H, Juntunen J, Laitinen M, et al. (2015) Effect of the orientation and fluid flow on the accumulation 571 of organotin compounds to Chemcatcher passive samplers. Environ Sci-Proc Imp 17(4):813-824. https://doi.org/10.1039/c4em00585f passive sampling in monitoring organotin compounds at a wastewater treatment plant. Environ Sci-Wat 

de la Cal A, Kuster M, de Alda ML, Eljarrat E, Barcelo D (2008) Evaluation of the aquatic passive sampler

Allan IJ, Knutsson J, Guigues N, Mills GA, Fouillac AM, Greenwood R (2007) Evaluation of the Chemcatcher and DGT passive samplers for monitoring metals with highly fluctuating water concentrations. J Environ Monitor 9(7):672-681. https://doi.org/10.1039/b701616f

Alonso JIG, Encinar JR, Gonzalez PR, Sanz-Medel A (2002) Determination of butyltin compounds in environmental samples by isotope-dilution GC-ICP-MS. Anal Bioanal Chem 373(6):432-440. https://doi.org/ 10.1007/s00216-002-1294-y

Berto D, Giani M, Boscolo R, et al. (2007) Organotins (TBT and DBT) in water, sediments, and gastropods of the southern Venice lagoon (Italy). Mar Pollut Bull 55(10-12):425-435. https://doi.org/10.1016/j.marpolbul.2007.09.005

Bezak N, Brilly M, Sraj M (2014) Comparison between the peaks-over-threshold method and the annual maximum method for flood frequency analysis. Hydrolog Sci J 59(5):959-977. https://doi.org/10.1080/02626667.2013.831174

Bloesch J, Burns NM (1980) A Critical-Review of Sedimentation Trap Technique. Schweiz Z Hydrol 42(1):15-55. https://doi.org/10.1007/Bf02502505

Blom LB, Morrison GM, Kingston J, et al. (2002) Performance of an in situ passive sampling system for metals in stormwater. J Environ Monitor 4(2):258-262. https://doi.org/10.1039/b200135g

Bryan GW, Gibbs PE (1991) Impact of Low Concentrations of Tributyltin (TBT) on Marine Organisms: A Review, In: M.C. Newman and A. W. McIntosh, Eds., Metal Ecotoxicology, Concepts and Applications, 1st ed. Lewis Publishers, Chelsea.

Champ MA, Seligman PF (Eds) (1996) Organotin - Environmental Fate and Effects, 1st ed. Chapman \& Hall, London.

Chemcatcher for the monitoring of highly hydrophobic compounds in water. Talanta 76(2):327-332. https://doi.org/10.1016/j.talanta.2008.02.049 
600 Choulakian V, Stephens MA (2001) Goodness-of-fit tests for the generalized Pareto distribution. 601 Technometrics 43(4):478-484. https://doi.org/10.1198/00401700152672573

602 Cole RF, Mills GA, Hale MS, et al. (2018) Development and evaluation of a new diffusive gradients in 603 thin-films technique for measuring organotin compounds in coastal sediment pore water. Talanta 178:670604 678. https://doi.org/10.1016/j.talanta.2017.09.081

605 Diez S, Abalos M, Bayona JM (2002) Organotin contamination in sediments from the Western 606 Mediterranean enclosures following 10 years of TBT regulation. Water Res 36(4):905-918. 607 https://doi.org/10.1016/S0043-1354(01)00305-0

608 Dowson PH, Bubb JM, Lester JN (1993) A Study of the Partitioning and Sorptive Behavior of Butyltins in 609 the Aquatic Environment. Appl Organomet Chem 7(8):623-633. https://doi.org/10.1002/aoc.590070805

610 Dowson PH, Bubb JM, Lester JN (1996) Persistence and degradation pathways of tributyltin in freshwater 611 and estuarine sediments. Estuar Coast Shelf S 42(5):551-562. https://doi.org/10.1006/ecss.1996.0036

Dubalska K, Rutkowska M, Bajger-Nowak G, Konieczka P, Namiesnik J (2013) Organotin Compounds: Environmental Fate and Crit Rev Anal Chem $43(1): 35-54$.

614 https://doi.org/10.1080/10408347.2012.743846

EC (2003) Regulation no782/2003 of the European Parliament and of the Council of the European Union, 616 of 14 April 2003, on the prohibition for oganotin compounds on ships. Official Journal of the European 617 Union L115/1-11.

618 EC (2008a) Directive 2008/105/EC of the European Parliament and the Council of 16 December 2008 on 619 environmental quality standards in the field of water policy. Official Journal of the European Union, 348, 84-97.

EC (2008b) Regulation no 536/2008 of 13 June 2009 giving effect to Article 6(3) and Article 7 of Regulation (EC) No 782/2003 of the European Parliament and the Council of 14 April 2003 on the prohibition of organotin compounds on ships and amending that Regulation OJ L 156/10 of 14.6.2009. 
EC (2009) European Union 2009/425/EC Commission Decision of 28 May 2009 amending Council

Directive 76/769/EEC as regards restrictions on the marketing and use of organostannic compounds for the purpose of adapting its Annex I to technical progress. Official Journal of the European Union L138:11-13

Fent K (1996) Organotin compounds in municipal wastewater and sewage sludge: Contamination, fate in treatment process and ecotoxicological consequences. Science of the Total Environment 185(1-3):151-159. https://doi.org/10.1016/0048-9697(95)05048-5

Filipkowska A, Kowalewska G, Pavoni B (2014) Organotin compounds in surface sediments of the Southern Baltic coastal zone: a study on the main factors for their accumulation and degradation. Environ Sci Pollut R 21(3):2077-2087. https://doi.org/10.1007/s11356-013-2115-x sampler calibration (Chemcatcher $(\mathrm{R})$ ) for environmental monitoring of organotin compounds: Matrix effect, concentration levels and laboratory vs in situ calibration. Talanta 219. https://doi.org/10.1016/j.talanta.2020.121316 passive sampler for monitoring selected polar and semi-polar pesticides in surface water. Environ Pollut 155(1):52-60. https://doi.org/10.1016/j.envpol.2007.10.037

Harino H, Fukushima M, Kurokawa Y, Kawai S (1997) Susceptibility of bacterial populations to organotin compounds and microbial degradation of organotin compounds in environmental water. Environ Pollut 98(2):157-162. https://doi.org/10.1016/S0269-7491(97)00133-4 https://doi.org/10.1007/s002449900416 
ISO 17353 (2004) Water quality: Determination of selected organotin compounds: Gas chromatographic method. International Organization for Standardization, Geneva, Switzerland, 28 September 2004.

Jahnke A, Witt G, Schafer S, Haase N, Escher BI (2017) Combining Passive Sampling with Toxicological Characterization of Complex Mixtures of Pollutants from the Aquatic Environment. Adv Biochem Eng Biot 157:225-261. https://doi.org/10.1007/10_2015_5014

Juntunen J, Ahkola H, Krogerus K, Huttula T (2020) New theory of time integrative passive samplers. Anal Chim Acta 1127:269-281. https://doi.org/10.1016/j.aca.2020.05.042

Kaitaranta J, Niemisto J, Buhvestova O, Nurminen L (2013) Quantifying sediment resuspension and internal phosphorus loading in shallow near-shore areas in the Gulf of Finland. Boreal Environment Research 18(6):473-487

Kansanen PH, Jaakkola T, Kulmala S, Suutarinen R (1991) Sedimentation and Distribution of GammaEmitting Radionuclides in Bottom Sediments of Southern Lake Paijanne, Finland, after the Chernobyl Accident. Hydrobiologia 222(2):121-140

Karjalainen J, Juntunen J, Keskinen T, et al. (2019) Dispersion of vendace eggs and larvae around potential nursery areas reveals their reproductive strategy. Freshwater Biol 64(5):843-855. . https://doi.org/10.1111/fwb.13267

Kawai S, Kurokawa Y, Harino H, Fukushima M (1998) Degradation of tributyltin by a bacterial strain 665 isolated from polluted river water. Environ Pollut 102(2-3):259-263. https://doi.org/10.1016/S02697491(98)00079-7

Kingston JK, Greenwood R, Mills GA, Morrison GM, Persson LB (2000) Development of a novel passive sampling system for the time-averaged measurement of a range of organic pollutants in aquatic environments. J Environ Monitor 2(5):487-495. https://doi.org/10.1039/B003532g 
Lau YL (1979) Laboratory Study of Cylindrical Sedimentation Traps. J Fish Res Board Can 36(10):12881291. https://doi.org/10.1139/f79-184

Lee RF, Valkirs AO, Seligman PF (1989) Importance of Microalgae in the Biodegradation of Tributyltin in Estuarine Waters. Environ Sci Technol 23(12):1515-1518. https://doi.org/10.1021/es00070a010

Lindholm-Lehto PC, Ahkola HSJ, Knuutinen JS (2018) Pharmaceuticals in processing of municipal sewage sludge studied by grab and passive sampling. Water Qual Res J Can 53(1):14-23. https://doi.org/10.2166/wqrj.2018.022

Luyten P (2013). COHERENS-A Coupled Hydrodynamical-Ecological Model for Regional and Shelf Seas: User Documentation. Version 2.5.1. RBINS-MUMM Report, Royal Belgian Institute of Natural Sciences. http://odnature.naturalsciences.be/coherens/

Mannio J, Mehtonen J, Londesborough S et al. (2011) Screening of hazardous industrial and household chemicals in the aquatic environment. The Finnish Environment 3/2011.

Olsen M, Petersen K, Lehoux AP, Leppänen M, Schaanning M, Snowball I, Øxnevad S, Lund E (2019) Contaminated sediments: review of solutions for protecting aquatic environments. Nordic Council of Ministers, TemaNord 2019:514, Copenhagen. http://dx.doi.org/10.6027/TN2019-514

Paasivirta J, Särkkä J, Maatela P, Welling L, Paukku R, Hakala H, Koistinen J, Herve S (1990) Organoklooriyhdisteiden kulkeutumistutkimus Keski-Suomen järvisedimenteistä. Vesi- ja ympäristöhallituksen monistesarja 280: 1-58. In Finnish.

Page DS, Ozbal CC, Lanphear ME (1996) Concentration of butyltin species in sediments associated with shipyard activity. Environ Pollut 91(2):237-243. https://doi.org/10.1016/0269-7491(95)00046-1

Persson LB, Morrison GM, Friemann JU, Kingston J, Mills G, Greenwood R (2001) Diffusional behaviour of metals in a passive sampling system for monitoring aquatic pollution. J Environ Monitor 3(6):639-645. https://doi.org/10.1039/B107959j 
695 Roth M, Jongbloed G, Buishand TA (2016) Threshold selection for regional peaks-over-threshold data. J 696 Appl Stat 43(7):1291-1309. https://doi.org/10.1080/02664763.2015.1100589

697 Sampath R, Venkatakrishnan H, Ravichandran V, Chaudhury RR (2012) Biochemistry of TBT-Degrading 698 Marine Pseudomonads Isolated from Indian Coastal Waters. Water Air Soil Poll 223(1):99-106. 699 https://doi.org/10.1007/s11270-011-0842-5

700 Schubert B, Heininger P, Keller M, Ricking M, Claus E (2012) Monitoring of contaminants in suspended 701 particulate matter as an alternative to sediments. Trac-Trend Anal Chem 36:58-70. 702 https://doi.org/10.1016/j.trac.2012.04.003

703 Seligman PF, Valkirs AO, Lee RF (1986) Degradation of Tributyltin in San-Diego Bay, California, Waters. 704 Environ Sci Technol 20(12):1229-1235. https://doi.org/10.1021/es00154a006

705 Seligman PF, Valkirs, AO, Stang PM, Lee RF (1988) Evidence for Rapid Degradation of Tributyltin in a 706 Marina. Marine Pollution Bulletin, 19(10), 531-534.

707 Stewart C, Demora SJ (1990) A Review of the Degradation of Tri(Normal-Butyl)Tin in the Marine708 Environment. Environ Technol 11(6):565-570. https://doi.org/10.1080/09593339009384897

709 Takahashi S, Mukai H, Tanabe S, Sakayama K, Miyazaki T, Masuno H (1999) Butyltin residues in livers 710 of humans and wild terrestrial mammals and in plastic products. Environ Pollut 106(2):213-218. 711 https://doi.org/10.1016/S0269-7491(99)00068-8

712 Vermeirssen ELM, Dietschweiler C, Escher BI, van der Voet J, Hollender J (2013) Uptake and release 713 kinetics of 22 polar organic chemicals in the Chemcatcher passive sampler. Anal Bioanal Chem 714 405(15):5225-5236. https://doi.org/10.1007/s00216-013-6878-1

715 Vieno N (2014) Hazardous substances at wastewater treatment project report, Vesilaitosyhdistyksen monistesarja nro 34, Finnish Water Utilities Association. In Finnish. 
717 Vrana B, Mills G, Greenwood R, Knutsson J, Svenssone K, Morrison G (2005a) Performance optimisation 718 of a passive sampler for monitoring hydrophobic organic pollutants in water. J Environ Monitor 7(6):612719 620. https://doi.org/10.1039/b419070j

720 Vrana B, Mills GA, Allan IJ, et al. (2005b) Passive sampling techniques for monitoring pollutants in water. 721 Trac-Trend Anal Chem 24(10):845-868. https://doi.org/10.1016/j.trac.2005.06.006

722 Vrana B, Mills GA, Dominiak E, Greenwood R (2006) Calibration of the Chemcatcher passive sampler for 723 the monitoring of priority organic pollutants in water. Environ Pollut 142(2):333-343 . 724 https://doi.org/10.1016/j.envpol.2005.10.033

725 Vrana B, Vermeirssen ELM, Allan IJ, Kohoutek J, Kennedy K, Mills GA, Greenwood R (2009) Passive 726 sampling of emerging pollutants in the aquatic environment: state of the art and perspectives. Position 727 Paper. NORMAN-Network of reference laboratories, research centre and related organisations for 728 monitoring of emerging environmental substances.

729 Wren DG, Taylor JM, Rigby JR, Locke MA, Yasarer LMW (2019) Short term sediment accumulation rates 730 reveal seasonal time lags between sediment delivery and deposition in an oxbow lake. Agr Ecosyst Environ $731 \quad$ 281:92-99. https://doi.org/10.1016/j.agee.2019.05.007 


\section{Supplementary Files}

This is a list of supplementary files associated with this preprint. Click to download.

- Supplementarydata.docx 